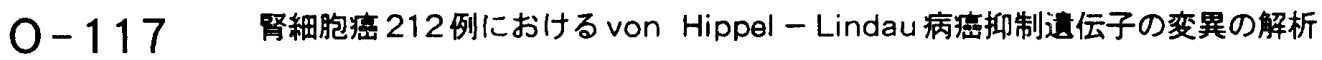

横浜市立大学 ${ }^{11}$ 、高知医科大学 ${ }^{21}$

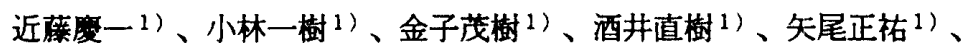

空田吉信 ${ }^{1)}$ 、穂坂正彦 ${ }^{11}$ 、執明太郎 21

von Hippel - Lindau病（VHL）は常染色体传性遭伝性で、中枢神経系の血管芽腫、網膜血管腫、堅 細胞癌、楬色細胞腫などを合併する。近年、この疾患の原因遺伝子としてVHL癌抑制遭伝子汸同定され た。この迹伝子はヒト染色体 3 番短脆 $25-26$ の領域に存在し、3つのエクンンを持ち、VHLにおいて

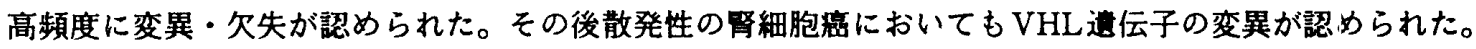
しかしいままでの報告では症例数が少ないため、堅細胞癌の発生・進展にVHL道伝子の変異林゙のよう に関与しているかはわかっていない。そこで今回われわれは関連施設の協力の下に散発性の堅沺胞福 212 例を集め、それらについてSouthern blot法、DNA - Single strand conformational polymorphism (DNA - SSCP) 法およびDirect sequence法を用いてVHL道伝子の变異の解析を行い、潪床像との 比較検討を行った。DNA - SSCP法ではエクンン 1 に34例、エクンン 2 に 32 例、エクンン 3 に 26 例 の変異を検出し、現在Direct sequence法による詳細な解析とSouthern blot法による比姣的大きな 变異の解析を行っている。

\section{O-118 ACDKおよびRCCに对するfreeironの関与についての検討}

\author{
東京女子医大

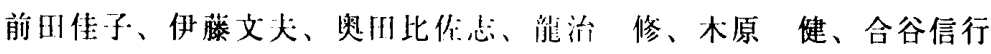 \\ 中沢速和、東開 紘
}

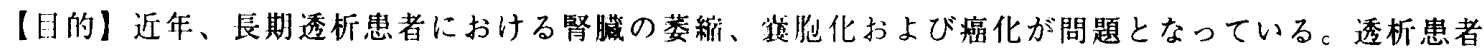

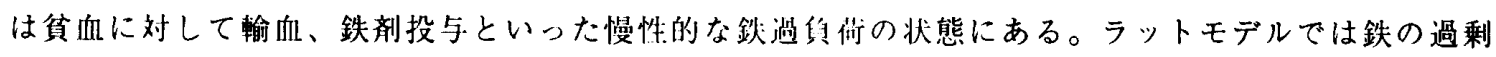

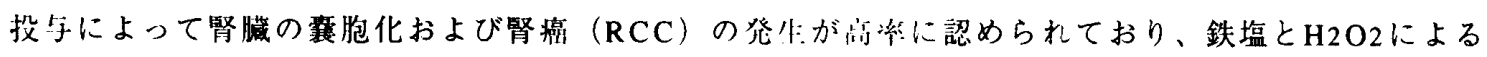

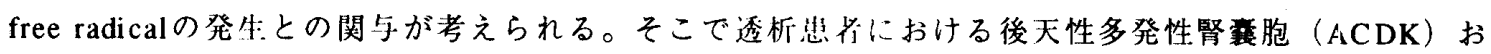
よびRCCに対するfree ironの関与について検荆した。

【対象と方法】対象はACDKを合併した透析患者 12例で、うち9例にRCCを合併していた。コントロ

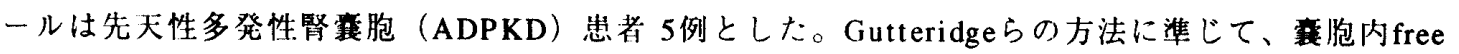
iron漲度を測定した。

【結果】free iron浱度は、RCC合併 ACDKでは 0-1.18 « M (中均 $0.35 \mu \mathrm{M}) 、 A D P K D$ と非RCC合併 $\mathrm{ACDK}$ では 0-0.45 $\mu \mathrm{M}$ (平均 $0.14 \mu \mathrm{M}$ ）であり、RCC介作 $\mathrm{ACDK}$ 症例で約 2.5 倍高值を示した。組織 内free iron濃度および過酸化反心によって生じるホスファチジールコリンヒドロパーオキ+イドの測 这も行い、合わせて検討し報告する予定である。 